\title{
The Tangent Solution to the Late Gothic Helical Staircase: A Justified Oblivion
}

\author{
Patricia Benítez Hernández • Mercedes Valiente López
}

Published online: 5 March 2015

(C) Kim Williams Books, Turin 2015

\begin{abstract}
In the late fifteenth century the helical staircase appeared in Spain as a representative element of late Gothic architecture. To gain a better understanding of this staircase and to carry out a proper preservation plan, it is essential to deepen our understanding of its construction and structure. This involves getting to know its geometrical configuration in depth, since its structural stability was ensured by rules of proportions. For this reason, this paper focuses on two broad types of staircases, classified according to the geometrical design strategy that solves the central aperture: the helical staircase by "radial solution" and by "tangent solution". The paper analyzes both solutions on the basis of objective criteria. In addition, it considers whether the limited use of some of these solutions was motivated by their particular geometry or was caused by other reasons is addressed. As result of this study it is demonstrated that although the two approaches solve the helical staircase in a similar way, the oblivion of the tangent approach was more objectively motivated.
\end{abstract}

\section{Introduction}

In the late fifteenth and early sixteenth centuries the helical or open-eyed staircase appeared in Spain as part of the Late Gothic style, which was also known as the mallorca staircase. It is one of the most representative elements of this architectural style. It is a modum hispaniae architecture (Romero 2006, p. 49) which has its roots in the Middle Ages. It co-existed for a while with the early Renaissance style and, therefore, it is not unusual to find this Gothic form in buildings of that new movement. This fact is an example of the Gothic legacy received by most of the new Spanish Renaissance architects as well as of the mutual influence that both movements had during the period in which they co-existed.

P. Benítez Hernández $(\bowtie) \cdot M$. Valiente López

ETSEM. Universidad Politécnica de Madrid, Avda. Juan de Herrera nº, 28040 Madrid, Spain e-mail: pbenitez@arquired.es 
The staircase is a key element for proper circulation in any multi-storey building. Nevertheless, the utilitarian nature of this kind of circular stair together with the fact that their location was usually hidden, since they were mainly for private use, have impeded the research on this type of element. Hence there are only a few studies (Calvo 2000; Palacio 2003; Rabasa 2007; Sanjurjo 2007, 2013; Benítez 2013; Benítez and Valiente 2014; etc.), which contribute to the analysis of this sort of stair. Indeed, in many cases the staircase itself is the only source of information and knowledge about the stair system. In order to understand this kind of circular stair and to carry out a proper preservation plan, it is essential to analyze their construction and structural aspects and processes. Thus, it is necessary to get an indepth understanding of their geometrical configuration, since the Gothic stonemasonry masters ensured structural stability through rules of proportions based on geometry. That is to say, the way the masters ensured the stability of a stone structure consisted in determining the right dimensions for all the different parts of the structural elements and achieving its correct form (Heyman 1999, pp. 30-31). If the form of the element does not change, it can be considered structurally safe (Heyman 1995, pp. 241-242).

The helical staircase is a simple element, which is shaped when a step-module revolves around a central axis. Nevertheless, at the time multiple geometrical designs were proposed (Sanjurjo 2013, p. 47). This was a result of the search for innovation that was typical during the Late Gothic period and a consequence of the high level of technical expertise of the stonemasonry masters. Among the different solutions proposed, only a few saw widespread use.

The aim of this analysis is to determine, following objective criteria related to comfort and safety, the reasons that could have motivated the limited use of some of these solutions. More specifically, one of the objectives of this work is to provide useful data to understand whether the predominant use of the traditional radial solution over the tangent one (Benítez and Valiente 2014, p. 8) was caused by their geometry or was motivated by other reasons.

As a result of this study it is proved that, although both designs solve the helical staircase in a really similar way, the fade into oblivion of the tangent approach was objectively motivated.

\section{The Helical Staircase and its Classification}

The helical staircase is considered an evolution of the spiral one (Sanjurjo 2007, p. 835$)^{1}$

\footnotetext{
1 The spiral staircase gets its name from the figure which can be seen from above the staircase. It is also known as the newel staircase. It is a circular stair in which all the treads are winders (Templer 1994a, b, p. 175). It is configured by a step with a rounded inner end, which uniformly moves around a central fixed axis in the horizontal plane as it simultaneously moves vertically. Thus, the central newel is formed when the steps are placed one on the other. In this sense, the straight imaginary line along the tip of the nosing of the treads generates a right helicoid as it translates uniformly in the direction of the vertical central axis of the staircase and at the same time moves about the helix contained in the enclosing walls cylinder.
} 
Both circular stairs have their antecedents in Greek and Roman Architecture. The oldest example of the spiral stair known to date can be found in the Greek Temple A at Selinunte (c. 490-460 BC) in Sicily. In Rome, Trajańs Column (113 A.D.) and Marcus Aurelius Column (176-192 A.D.) also have a spiral staircase, which runs up to a top platform that provides a panoramic view of the city. Despite the existence of these two early examples, Romans did not commonly use spiral staircases in buildings until the third century and onwards (Beckmann 2011, pp. 61-76). Thus, there can be found spiral staircases at the Baths of Caracalla (212-16 A.D.), the Baths of Diocletian (298-305 A.D.) and the Mausoleum of Constantia (c. 350 A.D.) among many others. In Spain, the oldest spiral stair can be found at the "Archaeological area of the Roman villa of Las Gabias" (sixth century A.D.), which is located to the south of the city of Granada.

With regard to the helical stair, the oldest examples can be found in the wellpreserved towers at Aghios Petros on Andros Island and Pyrgos Chimarrou on Naxos Island, both dated to the Hellenistic period (fourth to third century BC). These circular staircases, which are formed by stone steps embedded in the wall, have the distinctive inner well of helical stairs (Coulton 1977, pp. 149-150).

Nevertheless, these circular staircases were not widely used until the disappearance of the West Roman Empire (Templer 1994b, p. 53). The development of the craft guilds during the Middle Ages were decisive in their fast and wide spread, due to the standardized technical skills which were required for the construction of such elements (Templer 1994b, p. 54).

From that moment on, the spiral staircase became popular and was repeated in all types of buildings and countries: the Abbey Church at Cluny and Cathedral Notre Dame de Paris (France); the Basilica of the Holy Apostles in Köln and the Cathedral of St. Peter in Worms (Germany); and the Cathedral in Durham and in Canterbury (England) are only a few examples.

The helical stair did not reappear, however, until the late Gothic period at the end of the fifteenth century and was not fully developed until the early sixteenth century, when it was frequently used. The traditional helical stair gradually developed larger proportions and a richer decoration mainly composed of mouldings in the inner end of the step and the wall handrail. Over time, its enclosing walls also dissolved, improving the use of natural light (Fig. 1).

Another feature which was modified over the years was the intrados surface or soffit of the staircase. The early Gothic examples use steps of rectangular section, forming a stepped soffit, as can be seen in a spiral staircase at the old Cathedral of Salamanca (Spain) or the one located at Caernarfon Castle (Wales). This stepped soffit is considered less elegant than other approaches, but was easier to build (Campbell and Tutton 2013, p. 81). On the other hand, later staircases commonly present a smooth helical underside. In this case the soffit is built by using steps which are sloped at an angle to meet the next. Thus the rectangular section is cut to triangular, except a square portion in the outer end of the step, which is left to fit into the staircase wall masonry. We can find examples of stairs with such an underside at the Convent of Christ in Tomar (Portugal) (Fig. 1) and at the Santa Cruz Monastery in Segovia (Spain). Although it is more difficult to carve, this type of soffit is supposed to make the stair lighter and more beautiful (Fidler 1891, p. 107). There 
Fig. 1 Helical staircase.

Convent of Christ in Tomar (Portugal)

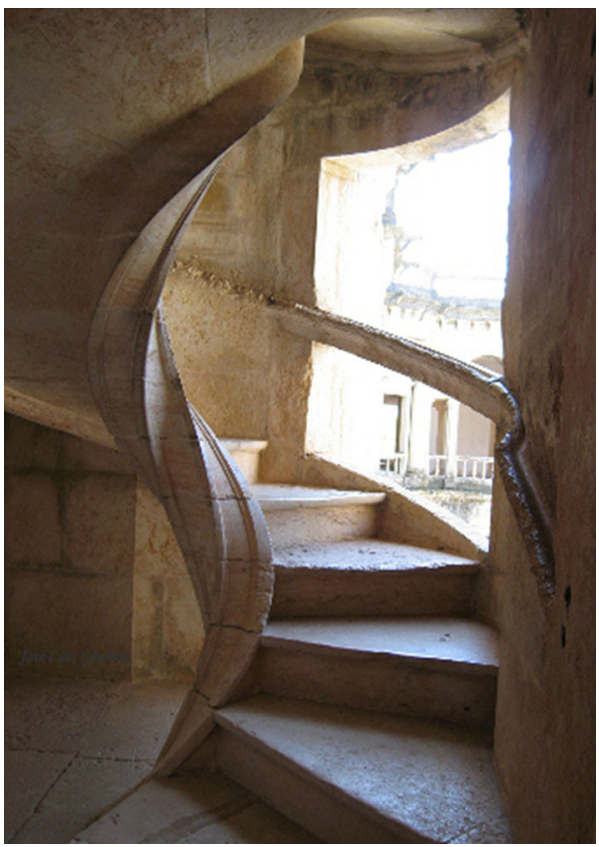

are other halfway solutions where the steps are neither of a rectangular section nor do they form a continuous surface; sometimes the step underside has a slight belly as in the staircase located at the Church of San Miguel in Jeréz de la Frontera (Spain); at other times, the external edges of the stepped soffit are chamfered as at Notre Dame de Paris (France) (Sanjurjo 2010, p. 558). A further elaborated version is the fluted helical soffit of the stair located at Castel Nuovo in Naples (Italy) or at la Lonja in Valencia (Spain).

All these changes resulted in a staircase which increasingly became a sculptural and significant element in Renaissance buildings. One of the most refined and relevant helical examples was designed by Donato Bramante for Pope Julius II at the Belvedere Palace (Templer 1994b, p. 68). It is a double helical staircase which was intended to separate the movement of people and animals. Actually, it contains two helical ramps of equal diameter with a common center, which start 180 degrees apart. Another well-known example of this type of double helical staircase can be found at the Chateau of Chambord, whose design is attributed to Leonardo da Vinci.

The helical stair has been repeated ever since in numerous buildings. Built out of stone or new materials like aluminum, steel or concrete it is easy to find them in modern constructions. In some cases they maintain the small-size, utilitarian nature and restrained decoration of the earlier age, as in the stairs located in apartments, libraries or even factories; others are spacious, elegant and even centerpieces of the building, like the one located at the exit of the Vatican Museum in Rome designed by Giuseppe Momo (1932), the free-standing helical staircase under the Glass 
Pyramid at the Louvre Museum in Paris (1989) or the new Exhibition Hall at the Deutches Historisches Museum in Berlin (2003), both designed by Ieoh Ming Pei.

The late Gothic helical staircase follows the fundamentals of Gothic architecture, just as the spiral one does, such as the use of standardized techniques, ease of construction and search for space-saving designs (Rabasa 2007, p. 746). From the point of view of the method of construction, the helical stair is a simple element with the same basic rule of generation as the spiral one: the rotation of a single-slabstep around a central axis. But in this case the newel seems to be replaced by a small well. Nevertheless, the newel is kept but it is not located in the geometric center of the staircase but around it (Calvo 2000, p. 224). In addition, it can be assumed that this twisting newel acts in a similar way to the vertical one of the spiral staircases (Campbell and Tutton 2013, p. 37). Thereby, the new central aperture allows natural light to illuminate the space, as well as improving the movement of people, as Andrea Palladio says in his first book of The Four Books of Architecture:

They succeed very well that are void in the middle, because they can have the light from above, and those that are at the top of the stairs, see all those that come up or begin to ascend, and are likewise seen by them. (Palladio 1965, p. 35)

According to the geometrical design employed to solve the central aperture, the late Gothic helical staircases can be classified into two broad types: "helical staircase by radial solution" and the "helical staircase by tangent solution" (Benítez and Valiente 2014, p. 8). There are additional versions that are a middle-way between both groups, such as the non-radial version described by Palladio (Palladio 1570. Book I chapter 28) and later included by Fray Lorenzo de San Nicolás in his treatise (de San Nicolás 1639, p. 119). This non-radial solution uses a step that neither points to the geometrical center of the stair nor is traced tangent to the open aperture. In this work, we have focused on these two broad types. Nevertheless, further research will be needed to account for these in-between traces.

\section{The Helical Staircase by Radial Solution: the Circular Sector Step}

This group has two essential features. The first one is that the longitudinal edges of the step, including the riser, coincide with the radius of the staircase circumference. The second common feature is that the length of the step never exceeds the radius length of the staircase. Taking into account both requirements, the stair is generated through a one-piece step of stone shaped as a circular sector and the central hollow is created by the reduction of the length of the step of the corresponding spiral staircase.

It is the most commonly used solution for the helical staircase, and it is possible to find it finished by different types of soffit in numerous constructions of that period.

This group includes important examples like the one which is considered to be the first helical staircase built in Spain and gives name to this solution: the mallorca staircase. It is located in one of the four turrets which finish off the building corners of La Lonja in the city of Palma. It was built with a smooth helical soffit between 1435 and 1446 and was designed by the master Guillem Sagrera. This staircase 
design, but with a fluted helical soffit, was used again by the master Pere Compte at La Lonja of Valencia between 1482 and 1498, which is said to be the first helical stair built in the Iberian Peninsula.

Initially related to the Mediterranean region, the helical staircase with radial solution achieved a widespread use within the whole Iberian Peninsula. Rodrigo Gil de Hontañón was the Spanish master who frequently used this solution in many of his works and contributed both to its refinement and to its rapid dissemination. We can find samples of helical stairs by radial design with different types of soffit in the Vélez Chapel in Murcia Cathedral which has a fluted helical soffit, Colegio de Arzobispo Fonseca in Salamanca which has a middle-way stepped soffit (Fig. 2), and the Concepción Chapel in Segovia Cathedral which has a smooth helical soffit, among many others examples (Sanjurjo 2007, p. 836).

Versions of the radial design were included from the very beginning in the Spanish stonemasonry treatises, probably as a consequence of being the most frequent design of helical stair to be built. The Declaración del caracol de mallorca (mallorca staircase statement) refers to this solution (Fig. 3), included in Alonso de Vandelvirás treatise Libro de trazas de cortes de piedras (De Vandelvira 1580, p. 51v); also the Caracol de ojo abierto (open-eyed staircase) attributed to R. Gil de Hontañón and included in the first six chapters of the treatise of Simón García's Compendio de architectura y simetría de los templos: conforme a la medida del cuerpo humano (García 1681, pp. 10v and 11r); the Caracol de ojo que dicen de mallorca (Eyed staircase called mallorca staircase) (Fig. 4) that Martínez de Aranda detailed in his treatise Cerramientos y trazas de montea (Martínez de Aranda (c. 1600) 1986, p. 234v); or the examples included in the texts of Alonso de Guardia (De Guardia c. 1600, pp. 50v and 51v) or Juan de Aguirre (De Aguirre c. 1600, p. 2r). During the seventeenth century, Fray Lorenzo de San Nicolás (De San Nicolás 1639, pp. 119r and 121v), Joseph Gelabert (Gelabert 1977, pp. 44v, 45r and $45 v$ ) and Juan de Caramuel also described this solution in their treatises (Caramuel

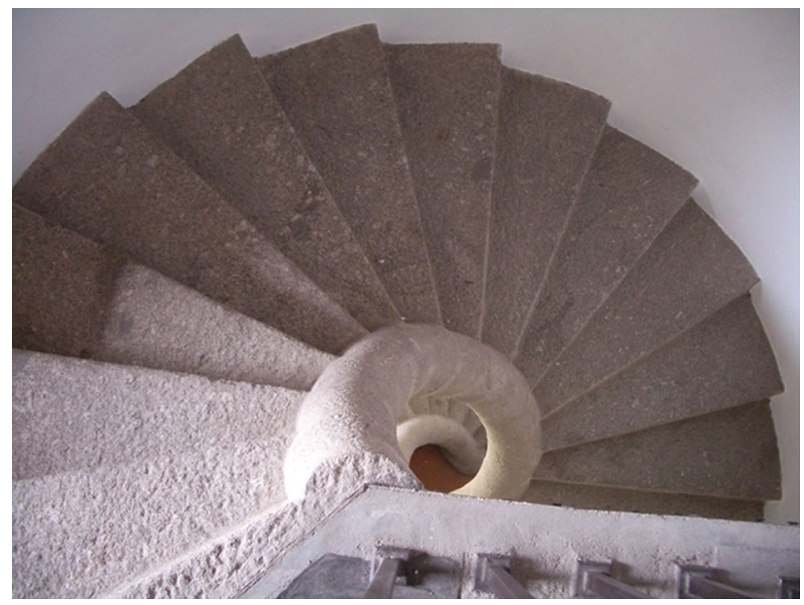

Fig. 2 Helical stair by radial solution. Colegio de Arzobispo Fonseca in Salamanca (Spain) 
Fig. 3 Declaración del caracol de mallorca. Helical stair described in Alonso de Vandelvira's treatise (1580)
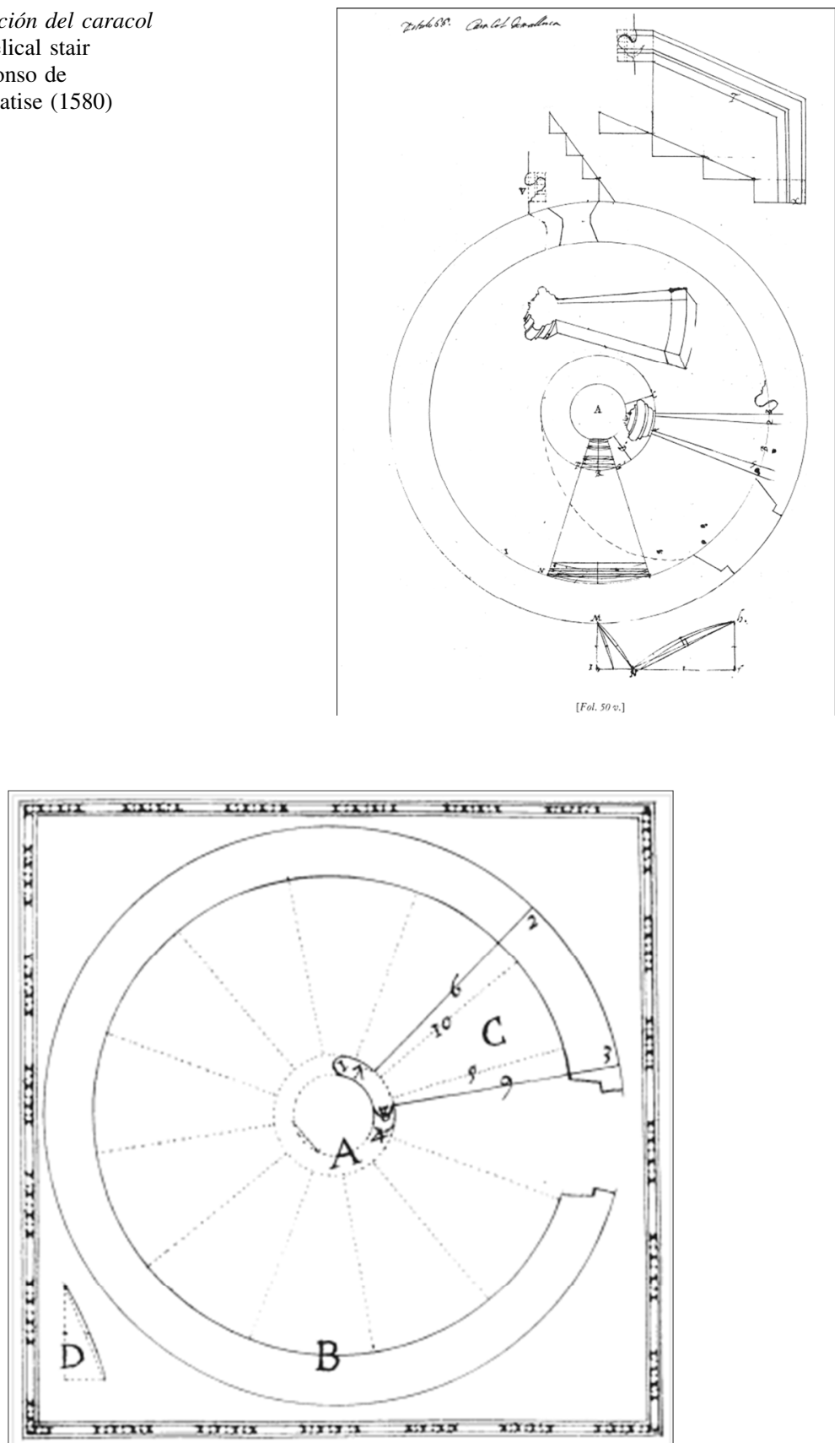

Fig. 4 Caracol de ojo que dicen de mallorca. Helical staircase described in Martínez de Aranda's treatise c. 1600 


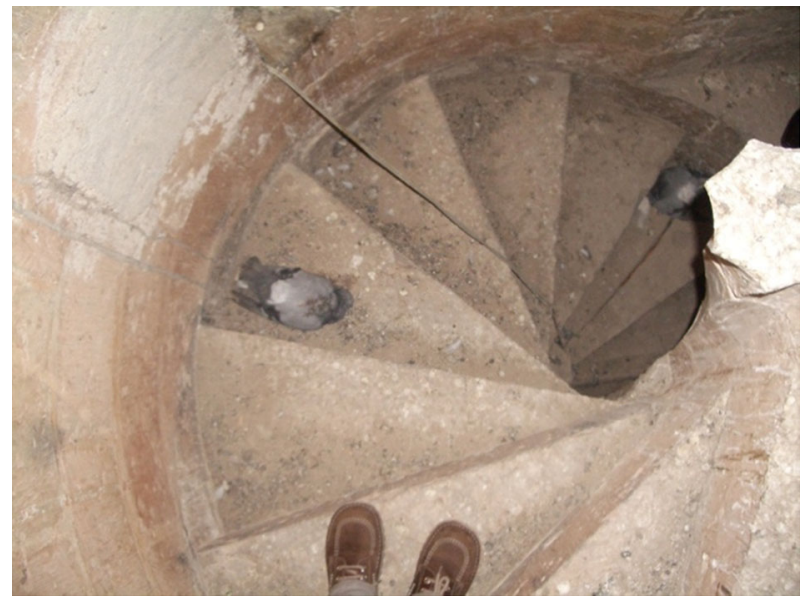

Fig. 5 Helical staircase by tangent solution. Monastery of Santa Cruz la Real in Segovia (Spain)

1678, tratado VI, p. 18). In the eighteenth century, Juan de Portor y Castro also included in his notebook drawings (Cuaderno de Arquitectura) examples of the radial solution for the helical stair. (Portor y Castro 1708, p. 24v).

\section{The Helical Staircase by Tangent Solution: the Fan-Shaped Module}

This solution employs a fan-shaped step (Carreiro 2007, p. 137). The configuration of this stair implies a riser tangent to the central hollow, and thus the increase in length of the step with respect to the radius of the staircase circumference. Therefore, the larger the central aperture is, the longer the step riser becomes.

It is a really unusual design, although it can be found in buildings constructed inland on the Iberian Peninsula even before the end of the fifteenth century. This is the case of the stair that is placed in the south wall of the church apse of the Monastery of Santa Cruz la Real in Segovia (Benítez 2013) (Fig. 5). It was designed with a smooth helical soffit by the royal master Juan Guas between 1478 and 1492, around the same time as the first helical stair that was erected in the Peninsula. But Santa Cruz is not the only example. Other helical staircases also follow this tangent design. One example is the third flight of the staircase located in the Tolosa Tower at Santiago Apóstol Church in Villa del Prado (Madrid) (Fig. 6). This was built with a stepped soffit by the master Tolosa in the mid-sixteenth century (Benítez and Valiente 2014, pp. 3-5). Other examples can also be found in the access to the attic at the Convent of Santa Catalina in Talavera de la Reina, and the access to the organ at the Cathedral of Plasencia, both with a smooth helical soffit (Sanjurjo 2013, p. 39).

Although the tangent solution is contemporary with the radial solution, it was not included in the first Spanish stonemasonry treatises of the end of the sixteenth century. 


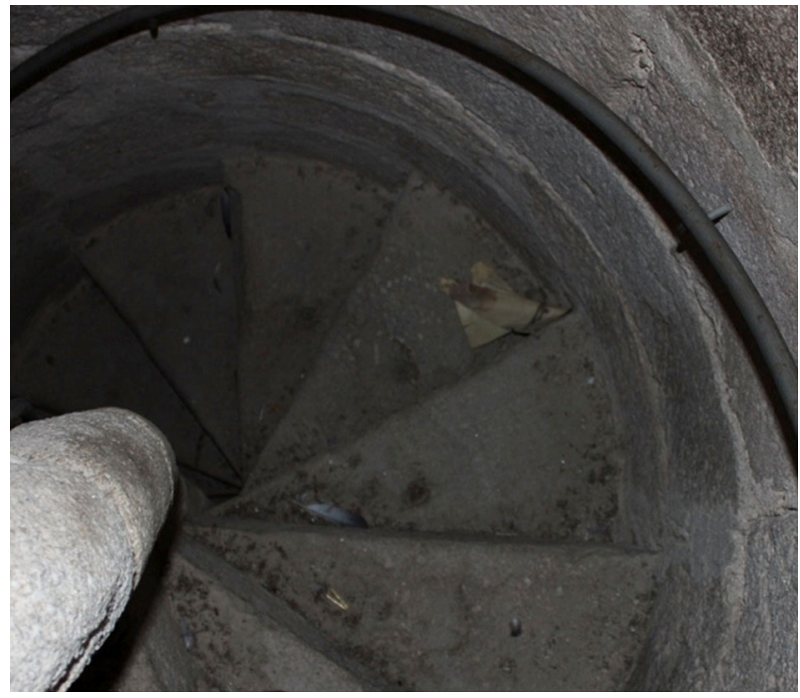

Fig. 6 Helical staircase by tangent solution. Church of Santiago Apóstol in Villa del Prado (Spain)

\section{Methods}

Any well-planned stair should provide an easy, quick and safe ascent/descent for those who use it. This issue concerns not only modern architects but also late Gothic stonemason masters (Templer 1994a, p. vi). In their treatises, they firstly solve a common comfort/safety issue: they determine the requirements for the appropriate movement of people on the stairway. Thereafter, they propose an approach to the related problem of stereotomy to meet these requirements.

As is known, movement on a stairway is mainly affected by the location of the stair, the light, the material, the stair geometry, and the presence of handrails. As mentioned above, in this work we focus on the stair geometry, in particular on how the geometrical design employed to solve the central aperture-radial or tangentaffects people walking on a stair. We address how the selection of a particular design involves variations on the comfort and safety level of a stairway.

The stair geometry factors which influence the circulation of people are: the headroom clearance, the number of steps, the height of the riser, the depth of the tread, and the width of the run. The first three factors are closely related to each other, since the height of the riser is determined by the number of steps per rotation and the minimum headroom required according to the soffit used. Additionally, the geometrical design employed to solve the central aperture only affects the determination of the depth of the tread and the width of the run.

In order to assess the effect of the design selection on these two factors, we have drawn the elementary geometrical outline of both designs (Fig. 7) and measured the main parameters which characterize the tread of their resulting step-module, since its dimensions determine both factors. 
To that purpose, firstly we have set the characteristic elements of the stair geometry which determine the tread dimensions and do not depend on the selected design: (a) the staircase diameter (b) number of steps per rotation and (c) the turning direction. As reference source, we have decided to take data from the staircase at the Monastery of Santa Cruz la Real in Segovia: (a) a staircase with $180 \mathrm{~cm}$ in diameter (b) fourteen steps per rotation which (c) rise anticlockwise (Benítez 2013, p. 95).

According to this data, we have solved the open-eyed staircase using both designs for different sizes of the central aperture. Specifically, we have considered central apertures with diameters of $20,25,30,35$ and $40 \mathrm{~cm}$. It is necessary here to clarify exactly what is meant by central aperture. In this case, it refers to the hollow that determines the basic geometry of the step without considering the partial reduction of its dimension that might occur due to the interior moulding.
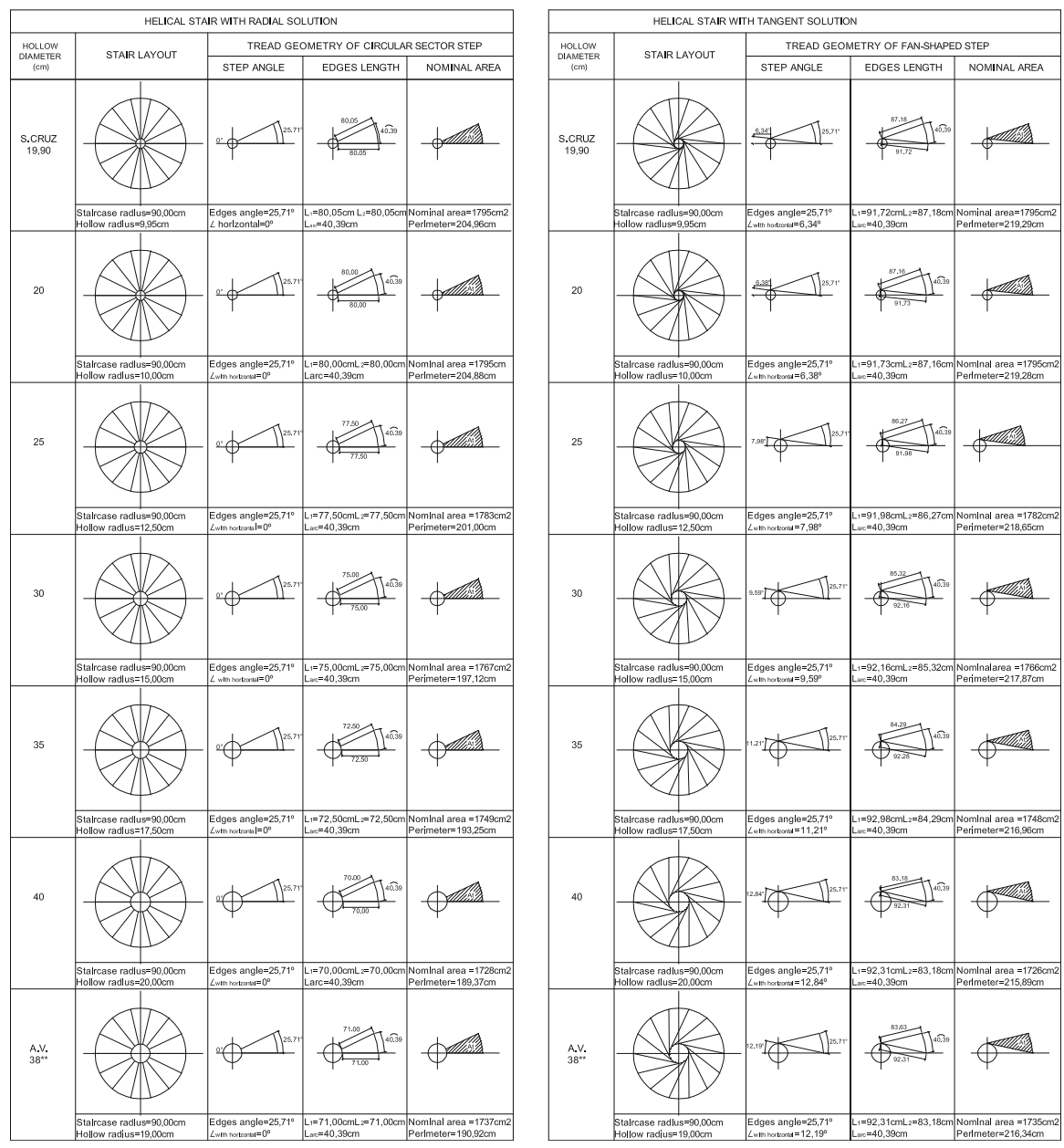

Fig. 7 Resulting elementary geometrical parameters of both solutions 
Afterwards, for each solution and central aperture size we have measured the geometrical parameters which determine the tread. In particular we have got values of: (a) nominal length of the step which determines the nominal width of the run (total distance across the tread from wall to central aperture); (b) effective length of the step (total distance across the tread from the walking line to a certain distance from the central aperture); (c) maximum depth of the tread (maximum chord length from the front of one tread to the front of the next); (d) depth of the tread measured at the walking line (chord distance measured at the walking line); (e) nominal tread area (total area measured from wall to central aperture); and (f) effective tread area (area measured from walking line to a certain distance from the central aperture).

Due to the step geometry of these circular staircases, the depth of the tread varies depending on the distance to the center of the staircase from where it is measured. Therefore it is important to determine the walking line $\mathrm{L}_{\mathrm{p}}$ or imaginary line which people are expected to walk along. The position of this line determines both the point where the going should be adequate, and the effective (or usable) values of the step. In this specific case of helical staircases, the literature suggests there is no unity of approach to the position of this line (Templer 1994b, p. 38). Therefore we have considered four different cases in order to measure the tread area (Fig. 8):

- Case I: the effective area (AuI) was measured from the outer side of the step next to the wall and the minimum tread width limited to $10 \mathrm{~cm}$, measured at right angles to the riser (Neufert 2013, p. 175).

- Case II: the effective area (AuII) was measured from the walking line to the minimum width of the tread. The walking line was considered $25 \mathrm{~cm}$ from the exterior wall (Carreiro 2007, p. 157). The minimum tread width was set at a value of $10 \mathrm{~cm}$ as in the previous case.

- Case III: the effective area (AuIII) was measured from the wider side of the step and the minimum width of the tread considered at a distance of $15 \mathrm{~cm}$ from the narrow side (Neufert 2013, p. 175).

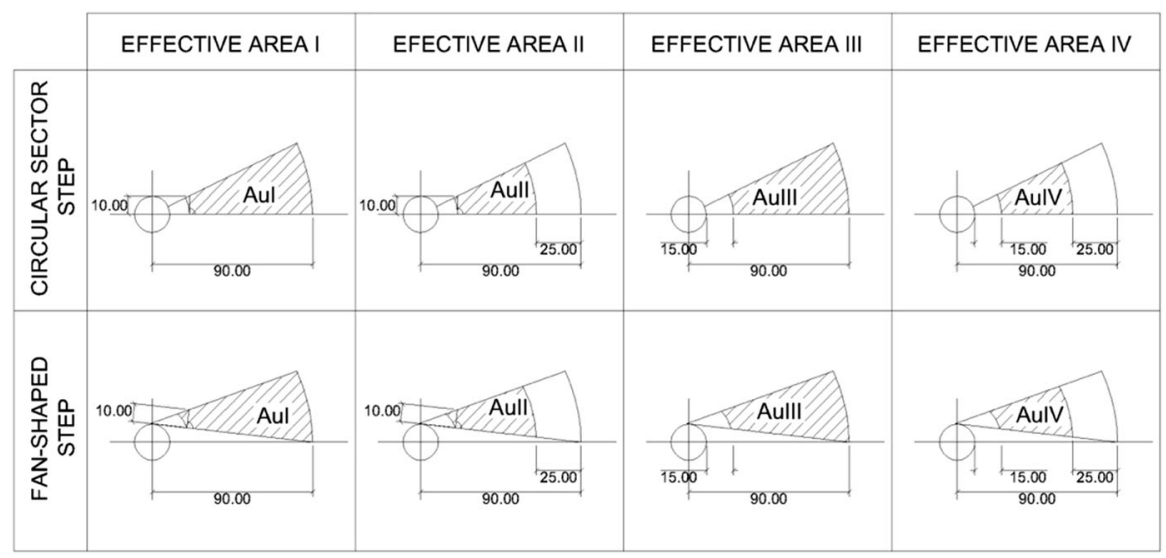

Fig. 8 Resulting effective area depending on the design and criterion employed in its calculation 
- Case IV: the effective area (AuIV) was measured from the walking line — set at a distance of $25 \mathrm{~cm}$ from the wall-to $15 \mathrm{~cm}$ away from the narrow side.

Afterwards, taking into consideration the potential impact of the geometrical design on the staircase construction, we have measured - for each design and size of central aperture - the volume of the smallest squared block of stone that can contain the templates of the one-piece step which are necessary for the stone-cutting. Therefore, an extra portion has been added to the tread area, which is required for supporting the next step, as well as the section needed for the interior moulding which finishes the central hollow. These two extra elements can be solved following different approaches, such as that proposed by Vandelvira or the one included by Martínez de Aranda in his treatise. With the purpose of assessing the results with built samples-source of rules of proportion according to the traditional method followed by the Late Gothic masters (Heyman 1999, p. 4) - it has been decided that the approaches to adopt in this study are: (a) the example proposed by Vandelvira in his treatise Libro de trazas de cortes de piedras for the radial solution (De Vandelvira 1580); (b) and the staircase of Santa Cruz la Real for the tangent solution (Benítez 2013).

According to these approaches, both extra portions were added to the tread area in the case of the fan-shaped module. On the contrary, in the radial solution we have to point out that only the extra portion required for supporting the next step has been added. According to Vandelvira, the moulding has been placed exactly in the very first $15 \mathrm{~cm}$ from the narrow side of the step.

It is worth noting that the employment of any particular soffit does not modify the dimensions of the squared block of stone required for the step carving, since each finished step can be inscribed in the obtained rough block, whatever soffit it presents.

\section{Results}

As mentioned before, the depth of the tread and the width of the run are two of the key factors in determining the comfort level of any staircase and the only ones that are affected by the geometrical design employed to solve the central aperture. In the helical stair both factors are determined by the tread dimensions of its step. Therefore, once the outlines of both designs have been defined, the treads of the resulting steps have been measured, analyzed and compared.

The following results can be extracted about the tread area:

- The nominal tread areas for all the considered central aperture sizes coincide in both solutions (Fig. 9).

With respect to the effective area, there is, however, a significant difference between the two solutions. It can be noted that:

- The effective tread area of the fan-shaped step does not exceed in any case that of the circular sector step, whatever criterion was employed in its calculation (Fig. 10a-d) 
- The effective tread area for a small central aperture with a diameter of $20 \mathrm{~cm}$, is similar in both designs, whatever criterion was employed in its calculation (Fig. 10a-d).

- The effective areas AuI and AuII are between 1 and $4 \%$ greater in the radial solution than in the tangent one. The gap between the two groups increases as the central hollow becomes larger (Fig. 10a, b).

- Interestingly, the resulting values for effective areas AuIII and AuIV perfectly coincide for both solutions as can be seen in Fig. 10c, d. Here it is important to remark that only these latter cases meet the requirements established by

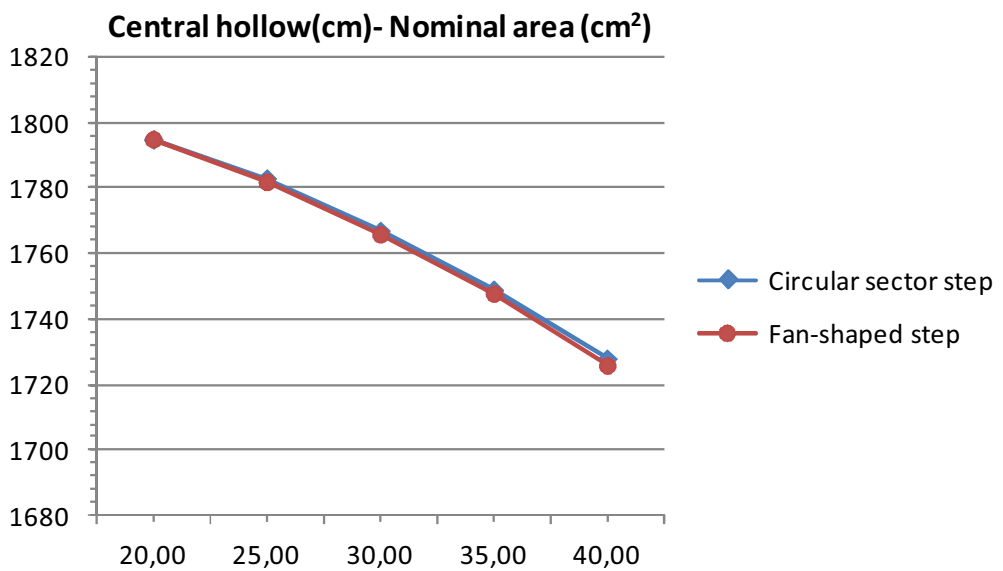

Fig. 9 Resulting nominal area of the tread with respect to the central hollow
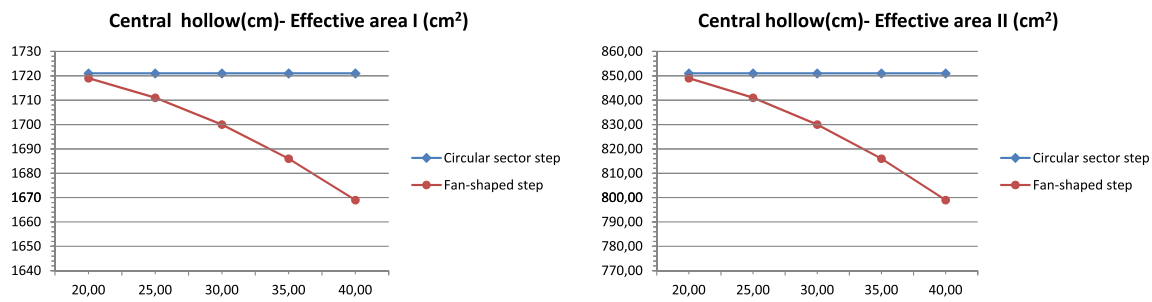

a Case I

b Case II
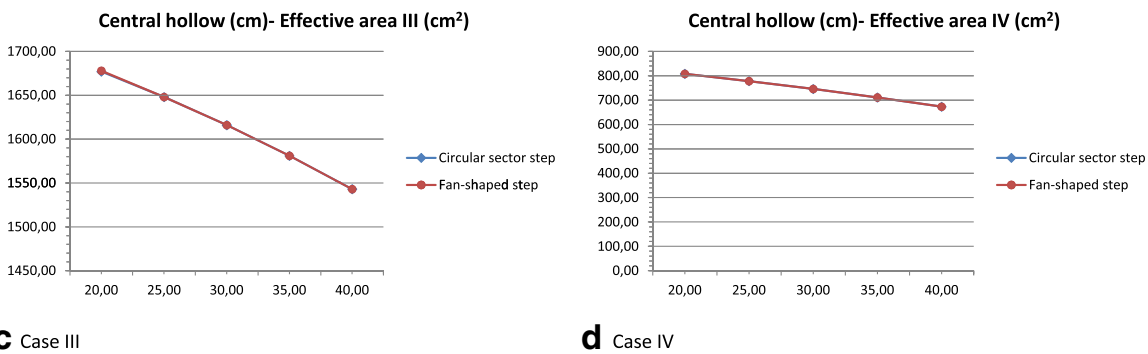

C Case III

Fig. 10 Resulting effective area of the tread with respect to size of the central hollow 
Table 1 Resulting effective areas of tread and difference depending on the employed design

\begin{tabular}{|c|c|c|c|c|c|}
\hline \multirow{2}{*}{ CENTRAL HOLLOW } & & \multicolumn{4}{|c|}{ USEFUL AREAS OF TREAD $\left(\mathrm{cm}^{2}\right)$} \\
\hline & & UAI & UAII & UAIII & UAIV \\
\hline \multirow{2}{*}{$20 \mathrm{~cm}$} & radial & 1721 & 851 & 1677 & 808 \\
\hline & tangent & 1719 & 849 & 1678 & 808 \\
\hline & Difference & 2 & 2 & -1 & 0 \\
\hline \multirow{2}{*}{$25 \mathrm{~cm}$} & radial & 1721 & 851 & 1648 & 778 \\
\hline & tangent & 1711 & 841 & 1648 & 778 \\
\hline & Difference & 10 & 10 & 0 & 0 \\
\hline \multirow{2}{*}{$30 \mathrm{~cm}$} & radial & 1721 & 851 & 1616 & 746 \\
\hline & tangent & 1700 & 830 & 1616 & 746 \\
\hline & Difference & 21 & 21 & 0 & 0 \\
\hline \multirow{2}{*}{$35 \mathrm{~cm}$} & radial & 1721 & 851 & 1581 & 711 \\
\hline & tangent & 1686 & 816 & 1581 & 711 \\
\hline & Difference & 35 & 35 & 0 & 0 \\
\hline \multirow{2}{*}{$40 \mathrm{~cm}$} & radial & 1721 & 851 & 1543 & 673 \\
\hline & tangent & 1669 & 799 & 1543 & 673 \\
\hline & Difference & 52 & 52 & 0 & 0 \\
\hline
\end{tabular}

Vandelvira for the interior moulding. In this sense the minimum going is considered at a distance of $15 \mathrm{~cm}$ from the narrow side; that is exactly one-sixth of the staircase radius as determined in Vandelvira's treatise.

Table 1 sums up the data about this issue.

If we now turn to the length of the step, which defines the width of the run, the results obtained are presented in Figs. 11, 12d. From this data we can observe that:

- The stairway solved by fan-shaped steps is wider than using circular sector ones.

- The nominal length for a central aperture of $20 \mathrm{~cm}$ in diameter is around $15 \%$ longer in the tangent solution than that in the radial one (Fig. 11).

- This gap increases as the central hollow becomes larger, since the length in the radial solution is clearly reduced while the one in the tangent design slightly grows. Thus the difference of nominal length increases up to $30 \%$ for a central aperture of $40 \mathrm{~cm}$ in diameter.

- The effective length difference is, however, significantly smaller. Figure 12a-d show how the effective length of the step in the tangent solution varies from 2-3\% (for a hollow with a diameter of $20 \mathrm{~cm}$ ), to 3-10\% (for a hollow with a diameter of $40 \mathrm{~cm}$ ). As happened with the effective area, in the latter two cases the difference between both designs is smaller than in the first two.

With respect to the tread perimeter, the following results can be extracted: 


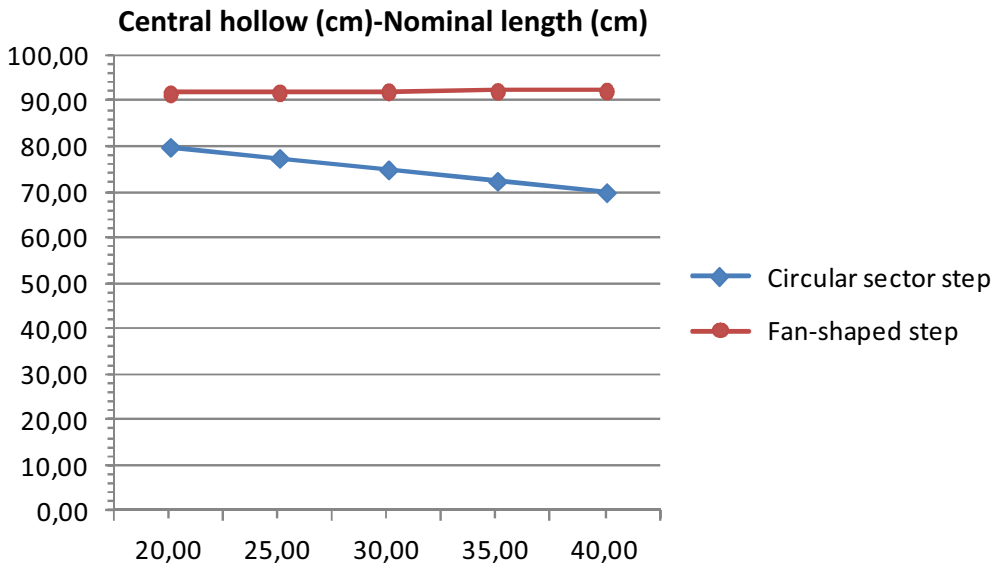

Fig. 11 Resulting nominal length of the step with respect to the size of the central hollow
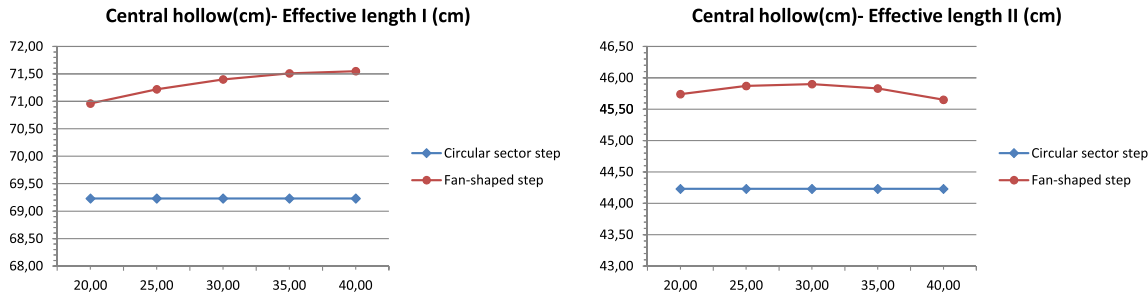

a Case I

b Case II
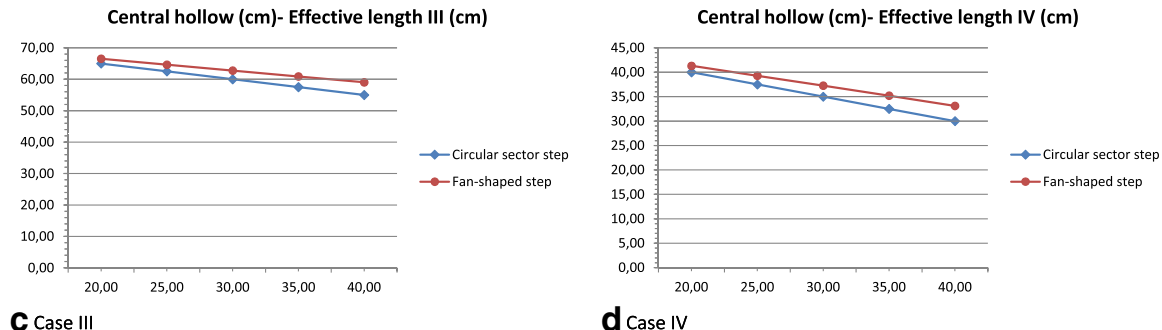

Fig. 12 Resulting Effective Length of the step with respect to the size of the central hollow

- The perimeter of the fan-shaped step is longer in all cases.

- For a similar nominal tread area, the tangent solution requires a perimeter about $7-15 \%$ longer than the traditional radial design.

- These values are reduced to 2-6\% when we consider the perimeter of effective areas.

Another important observation is that the depth of the tread in the walking line coincides in all cases for both designs and every size of the central hollow. This value is $28.93 \mathrm{~cm}$, which is slightly larger than one Castilian foot (one Castilian foot $=27.8635 \mathrm{~cm}$ ). 


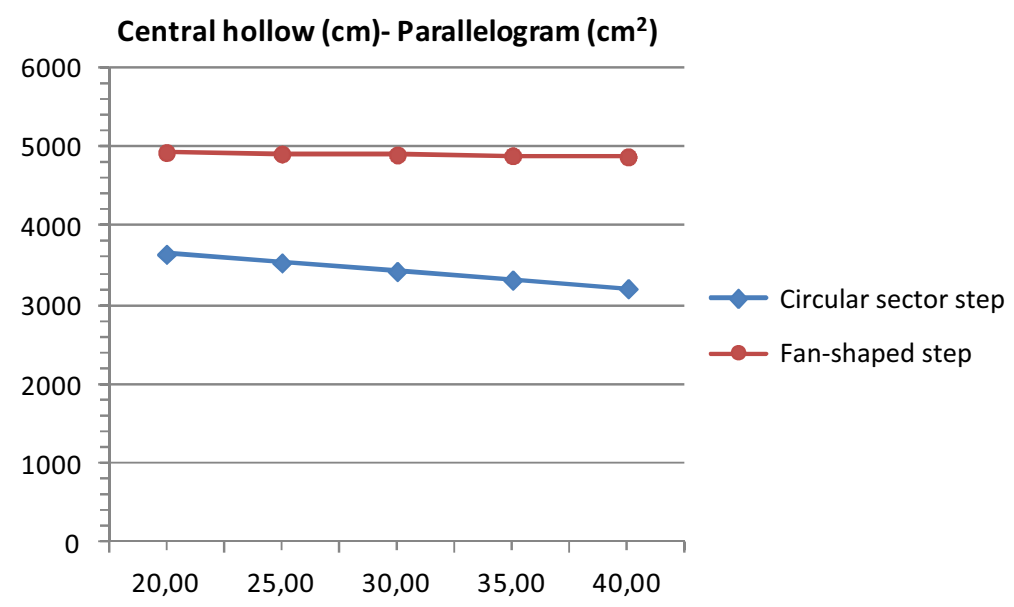

Fig. 13 Resulting areas of the upper side of the stone block with respect to the sizes of the central hollow

Finally, regarding the smallest squared block of stone that can contain the templates of the single-piece step, the results obtained are compared in Fig. 13. Considering the same height of the riser for both solutions (determined by the same number of steps per rotation, headroom clearance and soffit), it has only been necessary to compare the area of the upper side of the block. The results show that:

- The tangent solution requires a much larger block than the radial one does.

- The difference in the block size between both geometries grows, as the central aperture diameter enlarges.

- The required block for a fan-shaped step is between 35 and $52 \%$ larger than the one required for a circular sector step.

We can summarize these results by saying that when the central hollow has a diameter of $20 \mathrm{~cm}$, the step of the helical stair solved by a tangent design with respect to the radial one implies:

- Similar nominal and effective tread areas.

- $7 \%$ longer perimeter of the nominal area of the tread

- $15 \%$ longer nominal width of the stairway (or nominal length of the step). This percentage is reduced-depending on the criterion that was employed in the calculation-to only 2-3\% when we consider effective values;

- $35 \%$ larger stone block for each step.

If the central hollow has a diameter of $40 \mathrm{~cm}$, the step of the helical stair solved by a tangent design with respect to the radial one implies:

- a similar nominal total area of the tread;

- an effective tread area which-depending on the criterion used in its calculation — can be equal or even $6 \%$ smaller;

- $13 \%$ longer tread perimeter; 
Table 2 Percentages of the fan-shaped step related to the circular sector step

\begin{tabular}{lll}
\hline Helical staircase by fan-shaped steps & Central hollow & \\
\cline { 2 - 3 } & $\emptyset=20 \mathrm{~cm}$ & $\emptyset=40 \mathrm{~cm}$ \\
\hline Nominal tread area & $\approx$ & $\approx$ \\
Effective tread area & $\approx$ & $-6 \%$ \\
Perimeter & $+7 \%$ & $+13 \%$ \\
Nominal width of run & $+15 \%$ & $+32 \%$ \\
Effective width of run & $+2-3 \%$ & $+3 \%$ \\
Minimum stone block & $+35 \%$ & $+52 \%$ \\
\hline
\end{tabular}

- $32 \%$ longer nominal width of the stairway, that is reduced to only 3-10\% when we talk about effective values;

- and a $52 \%$ larger stone block.

Table 2 provides these data.

\section{Conclusion}

Knowledge about the geometry of Late Gothic circular staircases is important to carry out a proper preservation plan. Nevertheless, little has been found in the literature on this question, apart from the stonemasonry treatises. Regarding the helical staircase, two main layouts have been identified according to the geometrical design employed to solve the central aperture: the radial and the tangent. Although the first one is commonly addressed in those treatises, the tangent solution is seldom mentioned.

The present study has provided useful data to understand why this version did not have the same impact and was not as widespread as the traditional radial one. Specifically, it has set out to determine the effect of the central-hollow geometry on the comfort and safety level of both designs. It has contributed to finding out the advantages and disadvantages which each solution entails. The comparative analysis of the geometrical parameters of the tread of the different step-modules has identified the common design points, as well as the main differences between them.

For the purpose of a proper comparative analysis it has been necessary to set some general parameters of the helical stair. Namely (a) the staircase diameter, (b) the number of steps per rotation, (c) the turning direction and (d) the diameter of the central aperture.

Thus, it has allowed the correct comparison of the tread of their resulting stepmodules, which determines the depth of the tread and the width of the run, the only comfort factors which depend on the type of design employed. The findings have shown that both designs have similar values of nominal and effective tread areas. It has also been noted that the depth of the tread in the walking line are equal in both solutions. By contrast, there are two points in which both stair types differ: the width of the run determined by the length of the step and the material consumption.

Regarding the first one, the results of this study have shown that the tangent configuration has the advantage of having a longer step. This is an important issue if 
we take into account the characteristic small size of Late Gothic helical staircases, due to their utilitarian nature. A wider run is accomplished by fan-shaped steps. Thus, the circulation of people within the stair is improved without requiring a larger area. This point is in agreement with the ideas of Palladio (1570) and de San Nicolas (1639), who wrote in their treatises about the non-radial layout of the steps.

In addition, this study has quantified this advantage. The findings have shown that the nominal length of a fan-shaped step is between 15 and $30 \%$ longer than that of the circular sector module. However, the observed difference between both designs is reduced to 2-3\% or a maximum of $10 \%$ in the best case (but not the most used one), when we refer to effective length. Therefore, from the point of view of the width of the run, the tangent solution is the best option.

On the contrary, the same cannot be said about the issue of material consumption. According to the results obtained, the smallest stone block which can contain the templates of the fan-shaped step is around 35-52 \% larger than the block needed for the circular sector one. The consumption gap is higher for larger central aperture values. Therefore the radial solution is the most preferable option in this case.

To sum up, the tangent design implies that for similar tread area and going in the walking line, the steps are longer. First of all, it is necessary to remark that the apparent advantage of longer steps is not significant enough when we refer to effective values of step length. Therefore it does not imply a much higher comfort level. Secondly, it can also be concluded that the tangent method does not allow more steps per rotation than the radial one without reducing both parameters, tread area and going in the walking line. Thus, adding extra steps to the tangent solution would result in a disadvantage respecting the radial design. These results differ from those of Sanjurjo, who holds the view that the aim of the tangent solution to the helical staircase is most likely to arrange more steps per rotation or achieve more comfortable steps. (Sanjurjo 2013, p. 40).

However, the material consumption related to the staircase construction with the fan-shaped step considerably exceeds the amount of stone that is needed for a circular sector module.

As a consequence, a comparison of the findings has revealed that the tangent solution to the helical staircase does not provide significant benefits. On the contrary, it has the disadvantage of higher stone consumption which involves difficulties of transportation and movement during the construction of the staircase due to the excessive weight of the blocks, as well as higher material costs.

Taken together, the results of this study have shown that the radial solution is cheaper and easier to handle and thus the best solution to the helical staircase.

This research extends our knowledge of the Late Gothic staircase, and gives us evidence as to why the tangent solution was brushed aside by the stonemasonry masters of that period and faded into oblivion.

It would be interesting to compare these results obtained for the broad types with the middle-way examples, which have initially not been included in this study. 


\section{References}

Beckmann, M. 2011. The Column of Marcus Aurelius: The Genesis and Meaning of a Roman Imperial Monument. Chapel Hill: The University of North Carolina Press.

Benítez, P. 2013. Diseño y Construcción del Caracol de Mallorca de la Iglesia del Monasterio de Santa Cruz la Real (Segovia). In: VIII Congreso Nacional de Historia de la Construcción, (9-12 de Octubre 2013). Madrid: Instituto Juan de Herrera.

Benítez, P. and Valiente, M. 2014. From Spiral to Helical Stairs: Santa Cruz la Real and Santiago Apóstol Approaches. Rehab 2014-International Conference on Preservation, Maintenance and Rehabilitation of Historic Buildings and Structures (Tomar (Portugal), 19-21 March 2014), eds. Rogério Amoêda, Sérgio Lira and Cristina Pinheiro. Tomar: Green Lines Institute for Sustainable Development.

Calvo, J. 2000. Cerramientos y Trazas de Montea de Ginés Martínez de Aranda. Ph.d. thesis, Politécnica de Madrid.

Campbell, J. W. P. and Tutton, M. 2013. Staircases: History, Repair and Conservation. London: Routledge. Caramuel, J. 1678. Arquitectura Civil Recta y Oblicua. Vegeven. Imprenta Obispal por Camillo Corrado. Carreiro, M. 2007. El Pliegue Complejo. La Escalera. La Coruña: NETBIBLO, S.L.

Coulton, J. J. 1977. Greek Architects at Work: Problems of Structure and Design. London: Cornell University Press.

De Aguirre, J. c.1600. Manuscrito de Arquitectura y Cantería. Madrid: Biblioteca Nacional de España.

De Guardia, A. c.1600. Manuscrito de Arquitectura y Cantería. Madrid: Biblioteca Nacional de España.

De San Nicolas, F. L. 1639. Arte y Uso de Architectura. Compuesto por Fr. Laurencio de S Nicolas, Agustino Descalço, Maestro de obras.

De Vandelvira, A. 1580. Libro de trazas de cortes de piedras. Escuela Técnica Superior de Arquitectura de Madrid (E.T.S.A.M.): 49v-60r.

Fidler, H. 1891. Notes on Building Construction. London and New York: Longmans, Green and Co.

García, S. and Gil de Hontañón, R. c1681-1683. Compendio de Architectura y Simetría de los Templos: Conforme a la Medida del Cuerpo Humano, con Algunas Demostraciones de Geometría Recoxido de Dibersos Autores Naturales y Estrangeros por Simón García, Architecto natural de Salamanca. Biblioteca Nacional de España.

Gelabert, J. 1977. Vertaderas Traçes del Art de Picapedrer...:de l'art de Picapedrer (1653). Palma de Mallorca, Diputación Provincial de Baleares.

Heyman, J. 1995. Teoría, Historia y Restauración de Estructuras de Fábrica. Madrid: Instituto Juan de Herrera.

Heyman, J. 1999. El Esqueleto de Piedra: Mecánica de la Arquitectura de Fábrica. Madrid: Instituto Juan de Herrera.

Martínez de Aranda, G. 1986. Cerramientos y Trazas de Montea. Manuscrito c.1600. Madrid, CEHOPU. Neufert, E. 2013. Arte de Proyectar en Arquitectura. Barcelona: GG.

Palacio, J. C. 2003. Trazas y Cortes de Cantería en el Renacimiento Español. Madrid: Munillalería.

Palladio, A. 1965. The Four Books of Architecture (1570). New York: Courier Dover Publications.

Portor y Castro. 1708. Cuaderno de Arquitectura. Biblioteca Nacional de España Ms 9114.

Rabasa, E. 2007. De l'Art de Picapedrer (1653) de Joseph Gelabert, un Manuscrito Sobre Estereotomía que Recoge Tradiciones Góticas y Renacentistas. In: Actas de Quinto Congreso Nacional de Historia de la Construcción (Burgos, 7-9 Junio 2007), 745-754. Madrid: Instituto Juan de Herrera.

Romero, R. 2006. Un Cantero Tardogótico de Posible Ascendencia Cántabra en Castilla: Maestre Pero de Cubillas (1496-1525). Laboratorio de Arte 19: 49-66.

Sanjurjo, A. 2007. El Caracol de Mallorca en los Tratados de Cantería Españoles de la Edad Moderna. In: Actas de Quinto Congreso Nacional de Historia de la Construcción (Burgos, 7-9 Junio 2007), 835-846. Madrid: Instituto Juan de Herrera.

Sanjurjo, A. 2010. Otra Mirada a la Historia de la Construcción de Nuestras Catedrales: los Caracoles de Piedra y su Evolución. SEMATA, Ciencias Sociais e Humanidades 22: 555-566.

Sanjurjo, A. 2013. Experimentación Geométrica y Constructiva en Piedra: Algunos Casos Especiales de Escaleras de Caracol. Informes de la Construcción 65: 35-48.

Templer, J. 1994a. The Staircase: History and Theories. Cambridge, Massachusetts: MIT Press.

Templer, J. 1994b. The Staircase: Studies of Hazards, Falls and Safer Design. Cambridge, Massachusetts: MIT Press. 
Patricia Benítez Hernández studied architecture at the Escuela Técnica Superior de Arquitectura de Madrid (ETSAM) in the Universidad Politécnica de Madrid (UPM), and at the Reinisch Westfälische Technische Hochschule (RWTH) in Aachen (Germany). She received an Architecture degree with a Structural Design Specialty from the Universidad UPM in 1998. She began a PhD in 2008 at the same university, receiving the Diploma de Estudios Avanzados (DEA) in 2011. She is currently working on her $\mathrm{PhD}$ thesis. She taught Structural Design and Calculation Methods at the Architecture School of IE University in Segovia from 2003 until 2012. Her background includes work for companies in various fields of activity. Her research work is focused on Architectural Heritage. Her research interests lie in the influence that the integration of sustainability criteria and new materials have on structure, and on late Gothic stonemasonry in Spain.

Mercedes Valiente López studied Architecture in Madrid, specializing in building and town planning. She graduated in 1980 from the Escuela Técnica Superior de Arquitectura de Madrid (ETSAM) in the Universidad Politécnica de Madrid (UPM), where she got her PhD in 1990. Since 1992 she has been a Professor at the Department of Architectural Drawing at the Escuela Técnica Superior de Edificación de Madrid (ETSEM) at UPM. Since 2012 she has been Vice-Dean for Educational Innovation at ETSEM. She has participated in several research projects aimed at architecture, drawing and plan designs. In the professional area, she is a founder and collaborator in Valientés Architect Studio that has been running for more than 25 years. Her current interests include drawing, CAD, and architectural drawing. 